\title{
INTERACTIONAL FEEDBACK AND INSTRUCTIONAL COUNTERBALANCE
}

\author{
Roy Lyster \\ McGill University \\ Hirohide Mori \\ Nihon University
}

\begin{abstract}
This comparative analysis of teacher-student interaction in two different instructional settings at the elementary-school level (18.3 hr in French immersion and $14.8 \mathrm{hr}$ Japanese immersion) investigates the immediate effects of explicit correction, recasts, and prompts on learner uptake and repair. The results clearly show a predominant provision of recasts over prompts and explicit correction, regardless of instructional setting, but distinctively varied student uptake and repair patterns in relation to feedback type, with the largest proportion of repair resulting from prompts in French immersion and from recasts in Japanese immersion. Based on these findings and supported by an analysis of each instructional setting's overall communicative orientation, we introduce the counterbalance hypothesis, which states that instructional activities and interactional feedback that act as a counterbalance to a classroom's predominant communicative orientation are likely to prove more effective than instructional activities and interactional feedback that are congruent with its predominant communicative orientation.
\end{abstract}

This research was supported by Standard Research Grants (410-98-0175 and 410-2002-0988) awarded to the first author from the Social Sciences and Humanities Research Council of Canada and by a Nihon University Individual Research Grant for 2005 awarded to the second author. A version of this study was presented at the Second Language Research Forum held at Columbia University in October 2005. We are especially grateful to the participating teachers and their students and also to Yingli Yang for her role as research assistant in aggregating the datasets. We thank Sue Gass, Alison Mackey, Iliana Panova, Leila Ranta, and two SSLA reviewers for their helpful comments on earlier versions of this paper.

Address correspondence to: Roy Lyster, McGill University, 3700 McTavish St., Montreal, QC H3A 1Y2, Canada; e-mail: roy.lyster@mcgill.ca; or Hirohide Mori, Nihon University, 1-3-2 Misaki-cho, Chiyoda-ku, Tokyo 101-8360, Japan; e-mail: mori@eco.nihon-u.ac.jp. 
Since the 1970s, SLA researchers have investigated the role of interactional feedback in second language (L2) classrooms, based on the premise that learners benefit from information about the communicative success of their target language use (Long, 1977) and might require feedback on errors when they are not able to discover, through exposure to positive evidence alone, how their interlanguage differs from the target language (White, 1987). An increasing number of classroom studies continue to yield findings of both theoretical and pedagogical value and, at the same time, to confirm Chaudron's (1988) conclusion from almost 20 years ago that feedback is a "complex phenomenon with several functions" (p. 152). The complexity increases in content-based instruction, which "may result in unsystematic, possibly random feedback to learners about their language errors" (Allen, Swain, Harley, \& Cummins, 1990, p. 76) that arguably has a "detrimental effect on learning" (p. 67). To offset such detrimental effects and to improve the development of target language accuracy, researchers have called for the integration of focus on form (Doughty \& Williams, 1998; Long, 1991, 1996) or formfocused instruction (Ellis, 2001; Spada, 1997) into content-based or other communicatively oriented classrooms. Included in form-focused approaches are reactive interventions made by teachers in the form of interactional feedback.

\section{REACTIVE FOCUS ON FORM}

Interaction plays a key role in driving L2 development forward because learners rely on semantically contingent speech as a primary source of positive and negative L2 data (Long, 1996). In L2 classrooms, teacher-student interaction provides propitious opportunities for reactive focus on form to occur in relatively unplanned ways that include teacher feedback that targets students' nontarget output. Research in support of reactive focus on form suggests that it might be precisely at the moment when students have something to say that their attention can most effectively be drawn to form, rather than postponing attention to form until a subsequent language lesson (Lightbown, 1991, 1998; Long, 1991). Observational studies of French immersion classrooms provide detailed descriptions of how teachers interact with students by using a range of questioning techniques and feedback types to draw attention to form during language arts and science lessons (Lapkin \& Swain, 1996; Laplante, 1993; Lyster, 1994, 1998a). Similarly, Lightbown and Spada (1990) observed English as a second language (ESL) teachers who tended to focus on form on the fly, without interrupting the flow of communication. Spada and Lightbown (1993) described one teacher in particular who organized her teaching "in such a way as to draw the learners' attention to errors in their interlanguage development within the context of meaningful and sustained communicative interaction" (p. 218). 


\section{Interactional Feedback}

Based on descriptive studies of teacher-student interaction (Lyster, 2002; Ranta \& Lyster, in press), feedback moves can be classified as one of three types: explicit correction, recasts, or prompts. Explicit correction and recasts supply learners with target reformulations of their nontarget output. In the case of explicit correction, the teacher supplies the correct form and clearly indicates that what the student said was incorrect, as illustrated in (1). ${ }^{1}$

(1) Student: Le renard gris, le loup, le coyote, le bison et la gr . . groue. [phonological error]

"The gray fox, the wolf, the coyote, the bison and the cr ... cran."

Teacher: Et la grue. On dit 'grue'.

"And the crane. We say 'crane'."

For recasts, the teacher implicitly reformulates all or part of the student's utterance, as illustrated in (2).

(2) Student: Umi ya, umi ya ... [lexical error]

"The sea and, the sea and ..."

Teacher: Mizuumi ya. ..

"The lake and ..."

Prompts, on the other hand, include a variety of signals-other than alternative reformulations-that push learners to self-repair. These moves have been referred to elsewhere as negotiation of form (e.g., Lyster, 1998b; Lyster \& Ranta, 1997) or form-focused negotiation (Lyster, 2002). Along with Lyster (2004a) and Ranta and Lyster (in press), we refer to these moves as prompts, in order to avoid confusion with negotiation strategies that involve the negotiation of meaning and that aim for comprehensibility of message through various input and conversational modifications (e.g., Long, 1996; Pica, 1994). Prompts represent a range of feedback types that include the following moves (illustrated in Table 1): (a) elicitation, in which the teacher directly elicits a reformulation from the student by asking questions such as "How do we say that in French?" or by pausing to allow the student to complete the teacher's utterance, or by asking the student to reformulate his or her utterance; (b) metalinguistic clues, in which the teacher provides comments or questions related to the well-formedness of the student's utterance such as "We don't say it like that in Japanese"; (c) clarification requests, in which the teacher uses phrases such as "Pardon?" and "I don't understand" after learner errors to indicate to students that their utterance is ill-formed in some way and that a reformulation is required; and (d) repetition, in which the teacher repeats the student's ill-formed utterance, adjusting intonation to highlight the error.

Although these four prompting moves-used separately or in combinationrepresent a wide range of feedback types, they have one crucial feature in common: They withhold correct forms as well as other signs of approval (Lyster, 1998c) and, instead, offer learners an opportunity to self-repair by gener- 
Table 1. Prompts

\begin{tabular}{|c|c|c|}
\hline Type of prompt & Speaker & Student utterance + teacher prompt \\
\hline \multirow[t]{2}{*}{ (a) Elicitation } & Student & $\begin{array}{l}\text { Ben y a un jet de parfum qui sent pas très bon. . } \\
\text { [lexical error] } \\
\text { "Well there's a stream of perfume that doesn't } \\
\text { smell very nice..." }\end{array}$ \\
\hline & Teacher & $\begin{array}{l}\text { Alors un jet de parfum, on va appeler ça un ...? } \\
\text { "So a stream of perfume, we'll call that a ...?" }\end{array}$ \\
\hline \multirow[t]{2}{*}{ (b) Metalinguistic clue } & Student & $\begin{array}{l}\text { Kuruma. [lexical error] } \\
\text { "A car." }\end{array}$ \\
\hline & Teacher & $\begin{array}{l}\text { Kuruma janai yo. } \\
\text { "(It)'s not a car."a }\end{array}$ \\
\hline \multirow[t]{2}{*}{ (c) Clarification request } & Student & $\begin{array}{l}\text { Bashi ni. [phonological error] } \\
\text { "On the wagon." }\end{array}$ \\
\hline & Teacher & $\begin{array}{l}\text { Nani? } \\
\text { "What?" }\end{array}$ \\
\hline \multirow[t]{2}{*}{ (d) Repetition } & Student & $\begin{array}{l}\text { La guimauve, la chocolat. [gender error] } \\
\text { "Marshmallow, chocolate (fem.)." }\end{array}$ \\
\hline & Teacher & $\begin{array}{l}\text { La chocolat? } \\
\text { "Chocolat (fem.)?" }\end{array}$ \\
\hline
\end{tabular}

${ }^{\text {a} W o r d s ~ t h a t ~ d o ~ n o t ~ o c c u r ~ i n ~ t h e ~ J a p a n e s e ~ e x a m p l e ~ b u t ~ t h a t ~ a r e ~ n e c e s s a r y ~ f o r ~ t h e ~ E n g l i s h ~ t r a n s l a t i o n ~ a r e ~ i n c l u d e d ~ i n ~}$ parentheses.

ating their own modified response. Thus, prompts are pragmatically different from explicit correction and recasts. By prompting, a teacher provides cues for learners to draw on their own resources to self-repair, whereas by providing explicit correction or recasting, a teacher both initiates and completes a repair within a single move.

Research has shown that recasts are by far the most frequent type of feedback in a range of classroom settings: elementary immersion classrooms (Lyster \& Ranta, 1997; Mori, 2002), university-level foreign language classrooms (Doughty, 1994; Roberts, 1995), high school English as a foreign language (EFL) classrooms (Tsang, 2004), and adult ESL classrooms (Ellis, Basturkmen, \& Loewen, 2001; Panova \& Lyster, 2002). Research in immersion classrooms has shown that prompts are the next most frequent type of feedback after recasts, whereas explicit correction occurs with relative infrequency (Lyster \& Ranta; Mori). The following discussion of interactional feedback thus concerns recasts and prompts, which together are referred to throughout this paper as interactional feedback rather than corrective feedback. This choice reflects the observation that recasts and prompts are used by teachers in ways that sustain classroom interaction and maintain its coherence, but without consistently fulfilling a corrective function. In other words, the occurrence of both feedback types in classroom interaction is incontestable, but their mere occurrence is incommensurable with actual correction. 
Prompts and recasts can be seen as complementary moves with different purposes for different learners in different discourse contexts. Teachers can use one or the other in accordance with their students' language abilities and content knowledge, without abandoning one at the expense of the other (Lyster, 2002). Recasts are ideal for facilitating the delivery of complex subject matter because they provide supportive, scaffolded help, which serves to move lessons ahead when the target forms in question are beyond the students' current abilities. At the same time, recasts serve as exemplars of positive evidence (Braidi, 2002; Leeman, 2003) and, as such, can be expected to facilitate the encoding of new target representations when they occur in appropriate discourse contexts. Prompts, on the other hand, in their overt aim to elicit modified output without providing any exemplar of positive evidence, serve to improve control over already internalized forms by assisting learners in the transition of declarative to procedural knowledge (de Bot, 1996; Lyster, 2004a). Recasts and prompts thus elicit different types of learner responses-identified in classroom studies as different types of learner uptake and repair-as outlined in the next subsection.

\section{Learner Uptake, Repair, and Instructional Setting}

Uptake was defined by Lyster and Ranta (1997) as a student's immediate response to the teacher's feedback that "constitutes a reaction in some way to the teacher's intention to draw attention to some aspect of the student's initial utterance" (p. 49). The notion of uptake in classroom studies provides an effective tool for identifying patterns in teacher-student interaction that include a wide range of learner responses following teacher feedback, thus allowing for an operationalization of pushed output in classroom settings (Swain, 1985, 1988). Lyster and Ranta classified learner uptake as (a) utterances still in need of repair or (b) utterances with repair. Repair includes (a) repetition or incorporation of the correct forms provided in recasts and explicit correction and (b) self- or peer-repair following prompts. Uptake that involves self-repair requires a deeper level of processing than uptake that involves repetition, and it is arguably more effective at destabilizing interlanguage forms as learners are pushed to reanalyze interlanguage representations and to attend to the retrieval of alternative forms. In the context of adult EFL, McDonough (2005) found that self-repair moves that followed prompts in the form of clarification requests were significant predictors of L2 development. Similarly, Havranek and Cesnik (2001) found repair that followed prompts to be the most effective feedback combination in a range of EFL classrooms.

In contrast to self-repair that follows prompts, uptake that involves repetition of a recast does not engage learners in a similarly deep level of processing, nor does it necessitate any reanalysis. At least one laboratory study demonstrated that whether learners repeat recasts in the context of native 
speaker (NS)-nonnative speaker (NNS) interaction might even be unrelated to L2 development (Mackey \& Philp, 1998). Panova and Lyster (2002) suggested that uptake that consists of a repetition might not have much to contribute to L2 development because of its redundancy in an error treatment sequence in which the repair is both initiated and completed by the teacher within a single move. However, at least three studies suggest that uptake in the form of a learner's repetition of a recast is a reliable indicator of noticing and a good predictor of learning: (a) Mackey, Gass, and McDonough (2000) found that when learners repeated a recast, they were more likely to have correctly perceived its corrective intention; (b) Havranek and Cesnik (2001) found that recasts not eliciting immediate repetition by learners were the least effective type of feedback in EFL classrooms, as evidenced by follow-up language tests; and (c) Loewen (2005) showed that uptake that involved repetition of recasts was the best indicator of subsequent learning in adult ESL classroom settings. Yet the extent to which learners repeat recasts appears to vary according to instructional setting, with infrequent uptake observed in French immersion classrooms (Lyster \& Ranta, 1997), adult ESL in Canada (Panova \& Lyster), and EFL in Hong Kong secondary schools (Tsang, 2004), but more frequent (and successful) uptake observed in Japanese immersion classrooms (Mori, 2002), adult ESL classrooms in New Zealand (Ellis et al., 2001), and adult EFL conversation classes in Korea (Sheen, 2004). Nicholas, Lightbown, and Spada (2001) summarized the relationship between recasts and instructional setting:

Taken together, the results of the classroom studies indicate that the classroom context (particularly the communicative and/or content-based classroom) may make it difficult for learners to identify recasts as feedback on form and hence difficult for them to benefit from the reformulation that recasts offer. The exception may be some foreign language classrooms in which students' and teachers' focus is more consistently on the language itself. (p. 744)

Nicholas et al. (2001) thus argued that the effectiveness of recasts depends on the overall communicative orientation of a given instructional setting, with effectiveness increasing in more form-focused classrooms and decreasing in more meaning-focused classrooms. Additionally, Oliver and Mackey (2003) argued that within a given instructional setting, the particular interactional context within which a recast is provided also affects the overall effectiveness of recasts.

Notwithstanding a growing consensus that uptake "may create the conditions for language acquisition to occur" and "may be facilitative of acquisition" (Ellis et al., 2001, p. 287), there is an equally strong consensus that uptake alone does not constitute an instance of learning. Instead, the effect of interactional feedback and learner repair on longer term L2 development needs to be investigated in carefully designed quasi-experimental studies, such as those reviewed in the next subsection. 


\section{Classroom Experimental Studies}

Classroom studies of reactive form-focused instruction have demonstrated that oral feedback has a significant effect on L2 development in a variety of instructional settings that range from university-level foreign language classrooms to elementary classrooms that involve content-based ESL, communicative ESL, and French immersion. Together, these studies provide counterevidence to Krashen's (1994) and Truscott's (1999) contention that feedback is ineffective and even detrimental to L2 development.

In two classroom studies with young adult learners of French as a foreign language, Tomasello and Herron $(1988,1989)$ investigated the effects of feedback provided during teacher-led drills that used the garden path technique. In response to a set of transfer and overgeneralization errors that students were led to produce orally, the teacher first wrote the incorrect form on the chalkboard, then provided a recast orally and also wrote the correct form on the chalkboard. Both studies showed clear benefits for this type of explicit error treatment. The researchers designed the pedagogical intervention to include correct and incorrect forms written on the chalkboard, in addition to oral recasts, in order to allow time for visual and cognitive comparison. Tomasello and Herron (1989) concluded that, otherwise, "recasts do not seem to work in the L2 classroom" because "students in a classroom context believe that a teacher's positive response indicates that no correction is needed" (p. 392).

A similar attempt to make recasts appear salient was apparent in Doughty and Varela's (1998) study of two multilevel (from sixth to eighth grade) contentbased ESL classrooms. In the experimental classroom, students received feedback on simple past and conditional past tense forms during science activities. The other class engaged in the same science activities but without feedback. Two types of feedback-together called corrective recasting-were used in sequence. First, the teacher repeated the student's nontarget utterance, drawing attention to the error with stress and rising intonation; second, if the learner failed to respond, the teacher provided a recast in which the verb form was stressed. The corrective recasts were provided consistently by the teacher without any metalinguistic explanation, but her delivery was arguably at odds with the researchers' characterization of the double-feedback move as "implicit focus on form" (p. 118) that was only "slightly more explicit than recasts" (p. 124). Students' attention was further drawn to differences between nontarget and target forms via feedback provided on their written work. The study revealed short- and long-term benefits for feedback in comparison to no feedback at all, but shed no light on the effectiveness of implicit feedback in the form of recasts used on their own (i.e., not in the corrective recast sequence). Students appeared to benefit especially from the teacher's repetition of their nontarget utterances, as evidenced by the observation that by the beginning of the second of three treatment sessions, "students were beginning to self- 
correct before the teacher had the opportunity to recast" (p. 135). Because the teacher consistently used repetition to draw attention to the error and then used recasts only when students made no attempt at repair, the study provides more support for prompting techniques than for recasting-a finding that has been further substantiated in two recent classroom studies.

Ammar (2003) investigated the differential effects of prompts and recasts in form-focused instruction in three sixth-grade intensive ESL classrooms over a 4-week period. The form-focused intervention targeted third-person possessive determiners in English (his and her), which are known to be difficult for francophone learners of English even after many years of ESL instruction (White, 1998). Students in all three classes received form-focused instruction that included metalinguistic information and both controlled and communicative practice activities. During the practice activities, one class received feedback in the form of recasts, another received prompts (referred to as elicitation moves), and the third received no feedback. Results of pretests, immediate posttests, and delayed posttests showed that all three groups benefited from the form-focused instruction and that the two feedback groups benefited the most: Both outperformed the control group on immediate and delayed oral posttests, although the group that received prompts significantly outperformed the recast group on written and oral posttests. Ammar also found that prompts were particularly effective for lower proficiency learners, whereas higher proficiency learners appeared to benefit similarly from both recasts and prompts.

Lyster (2004a) also examined the differential effects of prompts and recasts with a pretest, immediate posttest, and delayed posttest design. A formfocused instructional unit on grammatical gender in French was implemented by three fifth-grade immersion teachers in different ways that permitted comparisons of three oral feedback options: prompts, recasts, and no feedback. A comparison group received neither form-focused instruction nor any preplanned feedback on grammatical gender. The analysis of eight proficiency measures (two oral tasks and two written tasks administered immediately following the instructional unit and then again 2 months later) showed that the group that received prompts distinguished itself by being the only group to significantly outperform the comparison group on all eight measures. The recast group significantly outperformed the comparison group on five of the eight measures, whereas the instruction-only (no feedback) group significantly outperformed the comparison group on four of the eight measures, which suggests that recasts were only marginally more effective than no feedback. Prompts proved to be especially instrumental in improving students' performance over time on the written tasks. In oral production, the superior performance of students who received prompts was evident at the time of immediate posttesting, but not 2 months later, when all students who received form-focused instruction-regardless of feedback treatment-significantly outperformed the comparison group in oral production. 


\section{Purpose of the Present Study}

Much interaction research strives to explain how L2 development is driven forward by conversational interaction. Theoretically motivated research of course aims to find common ground across contexts because learning mechanisms that are considered crucial in one setting should be equally relevant in another if they are to contribute to a theory of SLA. However, our review of classroom-based research into reactive form-focused instruction suggests that cognitive mechanisms considered to be instrumental in SLA might be triggered by a particular type of interactional feedback more effectively in one setting than another. Specifically, based on claims that children frequently repeat parental recasts during first language (L1) acquisition, recasts have been upheld as a type of feedback of prime importance, hypothesized to trigger noticing and to thereby promote L2 development (e.g., Doughty, 2001; Long, 1996; Long \& Robinson, 1998). Some classroom studies have indeed shown a tendency for learners to repeat recasts (Ellis et al., 2001; Mori, 2002), whereas in other studies, recasts have proven ineffective at eliciting repetition (Lyster \& Ranta, 1997; Panova \& Lyster, 2002; Tsang, 2004). With respect to longer term effects, corrective recasts proved more effective in comparison to no feedback in one classroom study (Doughty \& Varela, 1998), but prompts proved more effective than recasts in others (Ammar, 2003; Havranek \& Cesnik, 2001; Lyster, 2004a).

In light of such seemingly contradictory findings, we undertook the present study to compare patterns of interactional feedback, uptake, and learner repair in two different instructional settings: French immersion for English-speaking children in the predominantly French-speaking Canadian province of Quebec and Japanese immersion for English-speaking children in the United States. The aim is to increase our knowledge of relevant contextual variables that influence classroom learners' attentional biases toward one type of interactional feedback over another. Our research questions are formulated as follows:

1. What is the distribution of different types of interactional feedback in French and Japanese immersion classrooms?

2. What is the distribution of uptake and repair following different types of interactional feedback in French and Japanese immersion classrooms?

3. What factors contribute to similarities and differences in the occurrence of feedback, uptake, and repair across these two instructional settings?

\section{METHOD}

Contributions to this thematic issue of Studies in Second Language Acquisition were solicited for their potential to extend methodological boundaries in current interaction research. Our study does so in two ways. 
First, our comparative study contributes to a shift in interaction research from dyadic conversations to the realm of teacher-student discourse in language classrooms. Interaction research has typically examined conversational moves used to solve problems in message comprehensibility, generally operationalized as requests for clarification and confirmation of meaning along with comprehension checks. However, the relevance of these conversational moves in classroom interaction has not been consistently supported as central to L2 instructional practices (e.g., Aston, 1988; Foster, 1998; Lyster, 2002). Whereas communication breakdown and negotiation for meaning during conversational interaction are hypothesized to be essential catalysts for L2 development (e.g., Long, 1996), teacher-student interaction has a clearly pedagogical focus that relates not only to meaning but also to formal accuracy, quality of expression, and literacy development. Recent classroom studies have indeed shown that negotiation of form is more typical of teacher-student languagerelated episodes than negotiation of meaning (Ellis et al., 2001) and that formrelated episodes successfully lead to learner repair, whereas message-related episodes are sometimes never resolved (Loewen, 2004).

Second, our study adopts two coding schemes to compare two different instructional settings. First, we use Lyster and Ranta's (1997) error treatment model to identify specific patterns of interactional feedback, uptake, and learner repair in these two settings. Second, we use Spada and Fröhlich's (1995) communicative orientation to language teaching (COLT) coding scheme to identify similarities and differences in other instructional variables across the two settings. Using two coding schemes to support comparisons of instructional settings can be seen as a collaborative innovation that overcomes at least two problems inherent in much classroom SLA research: First, differences in coding categories across studies often prevent clear comparisons (Nicholas et al., 2001; Norris \& Ortega, 2000); second, studies that compare classrooms along a single dimension such as interactional feedback often lack other relevant descriptive data to support the comparison. As a result, we generalize beyond French and Japanese immersion settings in our conclusion and propose the counterbalance hypothesis, which states that the effectiveness of any one type of interactional feedback in a given instructional context is commensurate with the extent to which it differs from the classroom's overall communicative orientation. We propose the counterbalance hypothesis to help interpret our findings and to stimulate further research into the effectiveness of interactional feedback across a range of classroom settings.

\section{Participants and Database}

This comparative study analyzes interactional feedback and uptake that occurred during approximately $33 \mathrm{hr}$ of classroom interaction recorded in four French immersion (FI) and three Japanese immersion (JI) classrooms. 
The six participating teachers knew that the researchers were interested in recording classroom interaction but were unaware of the research focus related to interactional feedback. The teachers continued with their regular immersion program while a researcher oversaw the audio recordings of classroom interaction. To record information not captured by the audio recordings in the FI classrooms, a nonparticipant observer coded classroom activities using Part A of the COLT coding scheme (Spada \& Fröhlich, 1995). In the JI classrooms, video recordings were made of classroom activities, a subsample of which was then coded using COLT Part A.

Whether in FI or JI settings, teachers adopted a whole-language approach that integrated language skills across content areas and minimized explicit language instruction. In both settings, the content-based curriculum was designed to integrate a given theme across all subject-matter instruction at any one time. The teachers were so adept at blurring borders between language arts classes and subject-matter classes that it was often difficult to identify the type of class under observation.

French Immersion Classrooms. The data from FI classrooms used in the present study are from the four classrooms described in detail in Lyster and Ranta (1997); specifically, three are fourth-grade classrooms and the other is a split fourth/fifth-grade classroom. The four classrooms were in two different school boards with different immersion programs. School board A has an early total immersion program in which the students' school day-since first grade-was entirely in French except for about $1 \mathrm{hr}$ of English. School board B has a middle immersion program that begins in fourth grade, prior to which the students' school day was in English except for a 1-hr French lesson; beginning in fourth grade, the students' day is about 60\% in French and $40 \%$ in English.

One of the four classrooms observed was part of the early total immersion program, whereas the other three were middle immersion classrooms. The early immersion teacher was a female francophone who had taught for 21 years, which included 14 at the secondary level teaching French L1 and 7 in FI at the elementary level. Her 30 students came from a variety of language backgrounds, including 6 who spoke French at home. Students in the middle immersion program came primarily from English-speaking homes. Their class sizes were 26, 24, and 24. Of their three teachers, one was a female English/ French bilingual with 15 years of teaching experience, another was a female francophone with 8 years of teaching experience, which included 2 years in French L1 and 6 in FI, and the only male participant was an English/French bilingual who had taught for 5 years, which included 2 years in English and 3 years in FI.

Interaction in the four FI classrooms was audio-recorded and then transcribed by a native or nativelike speaker of French. All transcripts were verified at least once by a second transcriber who was again either a native or 
nativelike speaker of French. The database used for analysis in the present study includes 27 lessons that total 1,100 min, or $18.3 \mathrm{hr}$. There are 13 French language arts lessons (7.8 hr) and 14 subject-matter lessons (10.5 hr), which include lessons from science, social studies, and math.

Japanese Immersion Classrooms. Data from the three JI classrooms are part of a larger classroom study described by Mori (2002). Of the three classrooms in the present study, two were fourth-grade classes taught by the same teacher and the third was a fifth-grade class taught by a different teacher. All three classes were part of an early partial JI program at an elementary school in the United States. The JI program begins in kindergarten, which students attend for 2.5 days per week and where instruction is approximately $90 \%$ in Japanese and 10\% in English. At the elementary-school level, instruction is about 50\% in Japanese and 50\% in English. The data, totaling $889 \mathrm{~min}$, or $14.8 \mathrm{hr}$, include Japanese language arts lessons (10.9 hr), subject-matter lessons (2.1 hr), and other activities $(1.7 \mathrm{hr})$ that involved discussions before and after regular lessons, pertaining to topics such as classroom procedures, daily scheduling, attendance, and the weather.

The fourth-grade teacher had taught at the JI school for 7 years and, prior to that, had taught for 6 years at the elementary-school level in Japan. The fifth-grade teacher had taught for 9 years at the JI school, prior to which she had taught Japanese for 1 year at a junior high school, 1 year at a senior high school, and 6 years at the college level. Both teachers were Japanese-born female NSs of Japanese with nativelike competence in English. The fourthgrade classes each consisted of 20 students, whereas the fifth-grade class consisted of 29 students. All students were NSs of English from English-speaking homes with parents whose socioeconomic status was considered average.

Interaction in the three JI classrooms was both audio- and video-recorded. The audio recordings were transcribed by a NS of Japanese and then verified by a second transcriber who was also a NS of Japanese.

\section{Analysis of Interactional Feedback and Uptake}

The main unit of analysis in this comparative study is the error treatment sequence identified in Lyster and Ranta (1997, p. 44) and reproduced in Figure 1. This model has been adapted to investigate error treatment patterns in a range of classroom settings, including FI classrooms (Lyster, 1998b; Lyster \& Ranta, 1997), JI classrooms (Mori, 2000, 2002), ESL classrooms (Panova \& Lyster, 2002), EFL classrooms (Havranek, 2002; Sheen, 2004; Tsang, 2004), and German foreign language classrooms (Lochtman, 2002).

The error treatment sequence begins with a learner utterance that contains one or more errors, coded as either grammatical, phonological, or lexical, although the present analysis does not distinguish among error types. ${ }^{2}$ Topic continuation moves initiated by either students or the teacher can imme- 


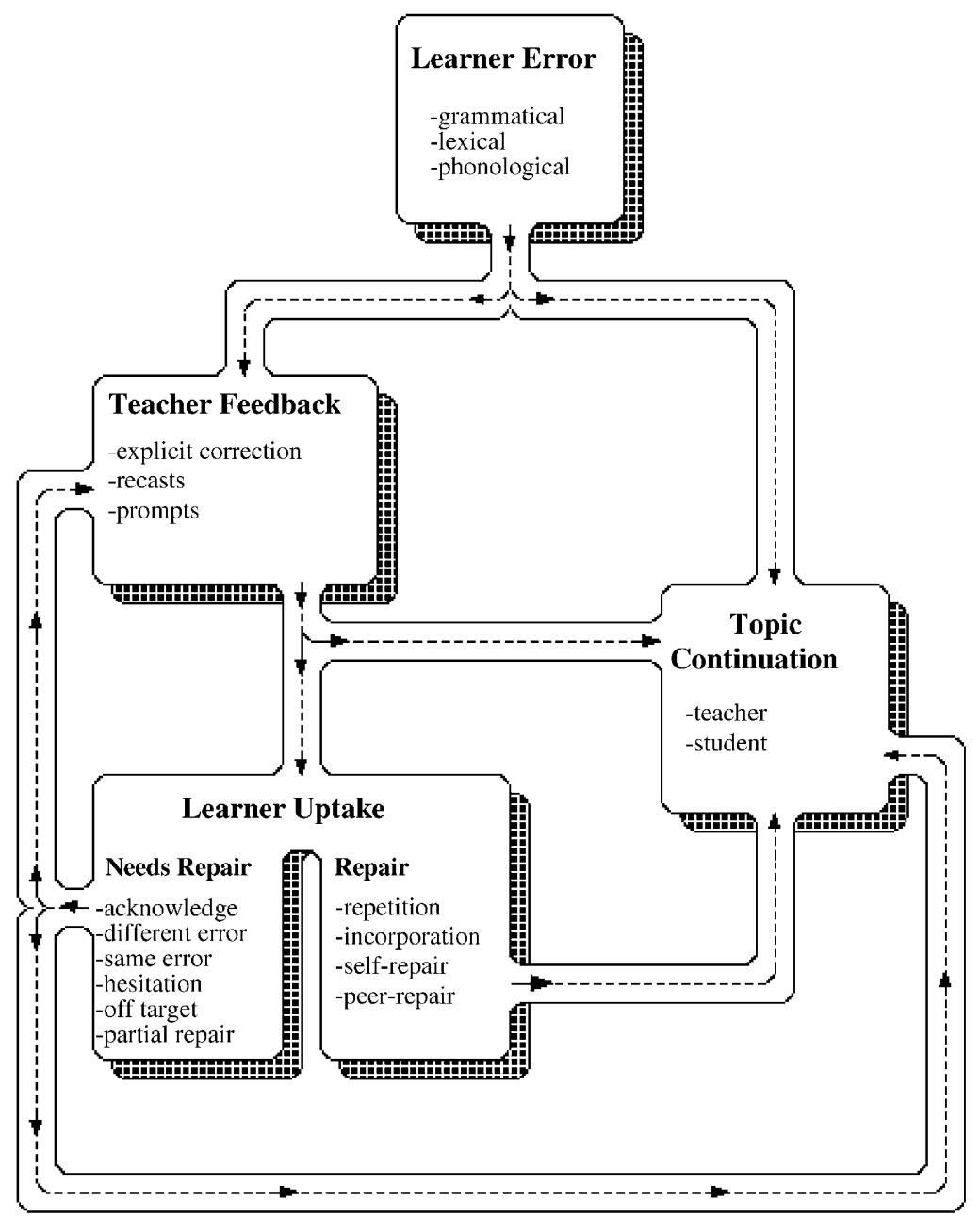

Figure 1. Error treatment sequence. Adapted from Lyster \& Ranta, 1997, p. 44.

diately follow learner utterances with error; so can feedback moves initiated by the teacher. The present study groups feedback moves as explicit correction, recasts, or prompts, as explained by the definitions and examples provided at the beginning of this paper.

Feedback moves can be followed either by topic continuation moves (initiated by a student or teacher) or by learner uptake, which refers to a student's immediate response to the teacher's feedback. Uptake includes two possibilities: repair or needs repair. Repair can occur in the following forms: learnergenerated repair (i.e., self-repair or peer-repair) and repetition or incorporation 
of a teacher's reformulation. Prompts can be followed by either self-repair or peer-repair: the former produced by the student who committed the error and the latter by a student other than the one who initially made the error. Repetition follows only recasts and explicit correction because these feedback types include the target form, which can be repeated or incorporated in a longer utterance. The category of needs repair refers to an utterance in which the student responds to the teacher's feedback move in some way but the uptake has not resulted in repair. Following Lyster and Ranta (1997), six subcategories were identified as needs repair: acknowledgment, same error, different error, off-target, hesitation, and partial repair.

Error treatment sequences that occurred in the FI and JI classrooms were identified in the transcripts and coded according to the above coding categories by two native or nativelike speakers of French in the case of the French data and a NS of Japanese in the case of the Japanese data; if necessary, a third or second researcher was consulted, respectively, until agreement was reached. Post hoc tests of interrater reliability conducted on a subset of $15 \%$ of the FI data and $23 \%$ of the JI data yielded levels of agreement of .84 and .95, respectively.

The FI data were imported into COALA (computer aided linguistic analysis; Thornton \& Pienemann, 1994) and the JI data were imported into CHILDES (child language data exchange system) for Japanese (Oshima-Takane, MacWhinney, Sirai, Miyata, \& Naka, 1998). These data analysis programs facilitated the quantification and identification of patterns that emerged in the aforementioned coding categories.

\section{Analysis of Communicative Orientation}

Stern $(1990,1992)$ described communicative language teaching strategies as complementary pairs of instructional options that vary along a continuum from analytic to experiential, explicit to implicit, and crosslingual to intralingual. Midway along the spectrum of analytic and experiential instructional options, Allen (1983) proposed a functional-analytic instructional approach that involves equal reference to language as a medium and language as communication. Allen and his colleagues developed the COLT observation and coding scheme (e.g., Allen, Fröhlich, \& Spada, 1984; Fröhlich, Spada, \& Allen, 1985; Spada \& Fröhlich, 1995) as a tool for observing L2 classrooms and for identifying pedagogical and organizational features that converge to make their communicative orientation more or less analytic, functional-analytic, or experiential.

COLT Part A was used in the present study to assess the overall communicative orientation of each instructional setting and to provide explanatory support for any differences across settings with respect to observed patterns of interactional feedback. The same $14 \mathrm{hr}$ of classroom interaction used for the analysis of interactional feedback in the JI classrooms were used in the COLT analysis. In the case of the FI classrooms, the COLT analysis targeted the same 
four classrooms but included a larger database of $30 \mathrm{hr}$ of coded interaction reported in an earlier study (Fazio \& Lyster, 1998). COLT Part A allows for observed pedagogical activities to be coded according to five main categories: participant organization, content, content control, student modality, and materials (type and source). More details about these coding categories can be found in the coding manual by Spada and Fröhlich (1995); some minor adaptations were made to accommodate immersion settings.

Participant organization characterizes the way in which students are organized during a given activity: as a whole class (in teacher-led, student-led, or choral activities), in groups, or in individual seat work. To code for the content of classroom activities, the observer differentiates among a classroom management focus, a language focus, a thematic focus, or combinations of more than one focus. In the third category, content control, a distinction is made about who controls the content of the observed activity: the teacher and text, the students alone, or a collaborative effort that involves the teacher, text, and students. Student modality focuses attention on whether students are listening, speaking, reading, or writing and whether these skills are integrated or used in isolation. COLT Part A also allows researchers to identify the type and source of materials used, but we were unable to obtain sufficiently accurate information about materials from the post hoc analysis of video recordings in the JI setting and, thus, omitted this category from the COLT analysis.

\section{RESULTS}

Table 2 presents a comparison of the total number of student turns in each instructional setting, along with the number of student turns with error and student turns followed by feedback. The dataset for each setting contains a similar number of student turns: 3,119 in the FI classrooms and 3,418 in the JI classrooms. A larger proportion of student turns with error occurred in FI (30\%; $n=945)$ than in JI classrooms $(13 \% ; n=428)$. Teachers in both settings, however, provided feedback after a similar proportion of errors: Of all student turns with error, 67\% were followed by feedback in FI classrooms $(n=635)$ and $61 \%$ were followed by feedback in JI classrooms $(n=259)$.

Table 2. Total student turns, turns with error, and turns followed by feedback

\begin{tabular}{lcc}
\hline Student turns & $\begin{array}{c}\text { French } \\
\text { immersion }\end{array}$ & $\begin{array}{c}\text { Japanese } \\
\text { immersion }\end{array}$ \\
\hline Total & 3,119 & 3,418 \\
With error & 945 & 428 \\
Followed by feedback & 635 & 259 \\
\hline
\end{tabular}


Table 3. Number and percentage distribution of learner uptake moves following feedback

\begin{tabular}{lccccc}
\hline & \multicolumn{2}{c}{$\begin{array}{c}\text { French } \\
\text { immersion }\end{array}$} & & \multicolumn{2}{c}{$\begin{array}{c}\text { Japanese } \\
\text { immersion }\end{array}$} \\
\cline { 2 - 3 } Move & $n$ & & & $n$ & $\%$ \\
\hline Uptake & 175 & $28 \%$ & & 124 & $48 \%$ \\
$\quad$ Repair & 173 & $27 \%$ & & 74 & $28 \%$ \\
$\quad$ Needs repair & 287 & $45 \%$ & & 61 & $24 \%$ \\
No uptake & 287 & & & & \\
\hline
\end{tabular}

Table 3 displays the number and percentage of learner uptake moves following feedback in both settings. The total amount of uptake following feedback was higher in JI classrooms: $76 \%$ of all feedback moves were followed by learner uptake in JI classrooms compared to 55\% in FI classrooms. Similarly, the proportion of uptake moves containing repair was greater in JI classrooms: Repair moves followed $48 \%$ of all teacher moves with feedback, whereas only $28 \%$ of teacher feedback moves led to immediate repair in FI classrooms. Topic continuation moves that immediately followed teacher feedback moveswith no attempt at or opportunity for uptake-were much more frequent in FI classrooms, where they followed $45 \%$ of student turns with error, than in JI classrooms, where they followed only $24 \%$ of student turns with error.

Table 4 displays the number and percentage distribution of prompts, recasts, and explicit correction in each setting. The proportions of each feedback type as used by teachers in both settings were quite similar (see Figure 2). In both settings, recasts comprised the largest proportion of feedback: $54 \%$ of all feedback moves in FI classrooms and 65\% of all feedback moves in JI classrooms. The next highest proportion of feedback moves in both settings was attributed to prompts, which comprised $38 \%$ and $26 \%$ of all feedback moves in FI

Table 4. Number and percentage distribution of feedback types

\begin{tabular}{lrrrrr}
\hline & \multicolumn{2}{c}{$\begin{array}{c}\text { French } \\
\text { immersion }\end{array}$} & & \multicolumn{2}{c}{$\begin{array}{c}\text { Japanese } \\
\text { immersion }\end{array}$} \\
\cline { 2 - 3 } \cline { 5 - 6 } Feedback type & $n$ & $\%$ & & $n$ & $\%$ \\
\hline Prompts & 244 & $38 \%$ & & 66 & $26 \%$ \\
Recasts & 345 & $54 \%$ & & 169 & $65 \%$ \\
Explicit correction & 46 & $7 \%$ & & 24 & $9 \%$ \\
\hline
\end{tabular}




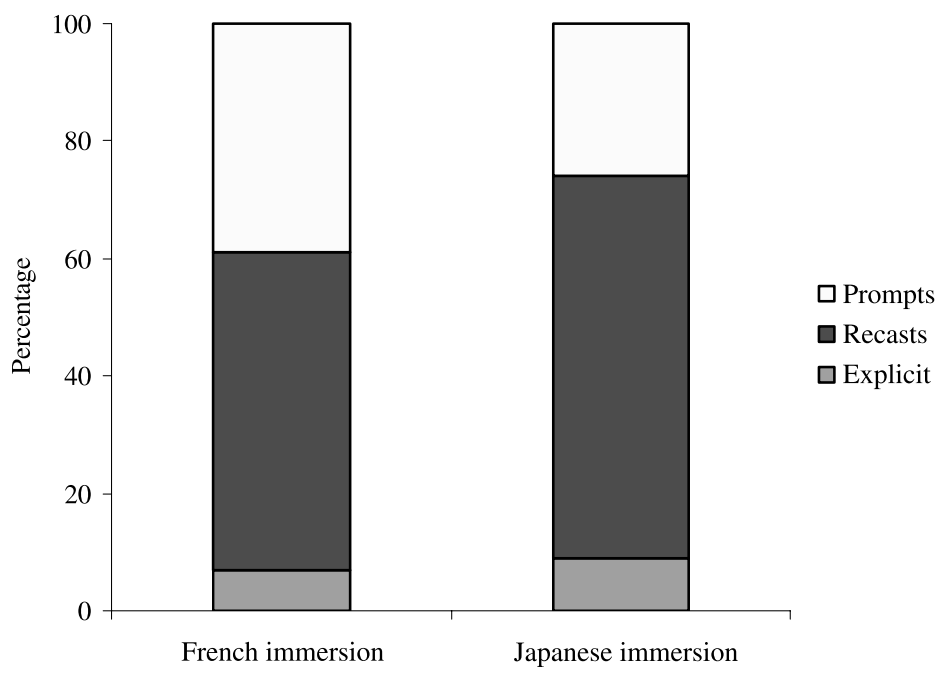

Figure 2. Percentage distribution of feedback types.

and JI classrooms, respectively. In both settings, it is interesting to note that explicit correction is relatively infrequent, comprising only $7 \%$ and $9 \%$ of all feedback moves in FI and JI classrooms, respectively.

Notwithstanding the similar distribution of feedback types across instructional settings, different patterns emerged in the analysis of uptake and repair following the different types of feedback. As seen in Table 5, the proportion of uptake after recasts and prompts was reversed in these two settings, with prompts accounting for almost twice as much uptake as recasts in FI classrooms and recasts accounting for twice as much uptake as prompts in JI classrooms. Specifically, of all student uptake moves in FI classrooms, 62\% followed prompts and $32 \%$ followed recasts; in contrast, of all student uptake moves in JI classrooms, $30 \%$ followed prompts and $61 \%$ followed recasts. The remain-

Table 5. Number and percentage distribution of uptake moves after each feedback type

\begin{tabular}{lrrrrr}
\hline & \multicolumn{2}{c}{$\begin{array}{c}\text { French } \\
\text { immersion }\end{array}$} & & \multicolumn{2}{c}{$\begin{array}{c}\text { Japanese } \\
\text { immersion }\end{array}$} \\
\cline { 2 - 3 } \cline { 6 - 7 } Uptake context & $n$ & $\%$ & & $n$ & $\%$ \\
\hline After prompts & 215 & $62 \%$ & & 59 & $30 \%$ \\
After recasts & 110 & $32 \%$ & & 121 & $61 \%$ \\
After explicit correction & 23 & $7 \%$ & & 18 & $9 \%$ \\
\hline
\end{tabular}


Table 6. Number and percentage distribution of repair moves after each feedback type

\begin{tabular}{lrrrrr}
\hline & \multicolumn{2}{c}{$\begin{array}{c}\text { French } \\
\text { immersion }\end{array}$} & & \multicolumn{2}{c}{$\begin{array}{c}\text { Japanese } \\
\text { immersion }\end{array}$} \\
\cline { 2 - 3 } Repair context & $n$ & $\%$ & & $n$ & $\%$ \\
\hline After prompts & 93 & $53 \%$ & & 28 & $23 \%$ \\
After recasts & 66 & $38 \%$ & & 84 & $68 \%$ \\
After explicit correction & 16 & $9 \%$ & & 12 & $10 \%$ \\
\hline
\end{tabular}

der of student uptake moves in both settings followed a similarly small proportion of explicit correction: 7\% in FI classrooms and 9\% in JI classrooms.

The different effects that prompts and recasts have on learner uptake in each setting are also reflected in the effects of these feedback types on immediate learner repair; that is, the proportion of learner repair moves that followed prompts and recasts was again reversed in each setting, as displayed in Table 6 and graphically in Figure 3. Of all repair moves in FI classrooms, $53 \%$ followed prompts and $38 \%$ followed recasts. In JI classrooms, of all learner repair moves, $23 \%$ followed prompts and $68 \%$ followed recasts. Explicit correction once more proved similar in both settings, accounting for small amounts of learner repair: 9\% in FI classrooms and 10\% in JI classrooms.

Another way of analyzing these data is to display the percentage distribution of uptake in terms of its presence (as repair or needs repair) or absence

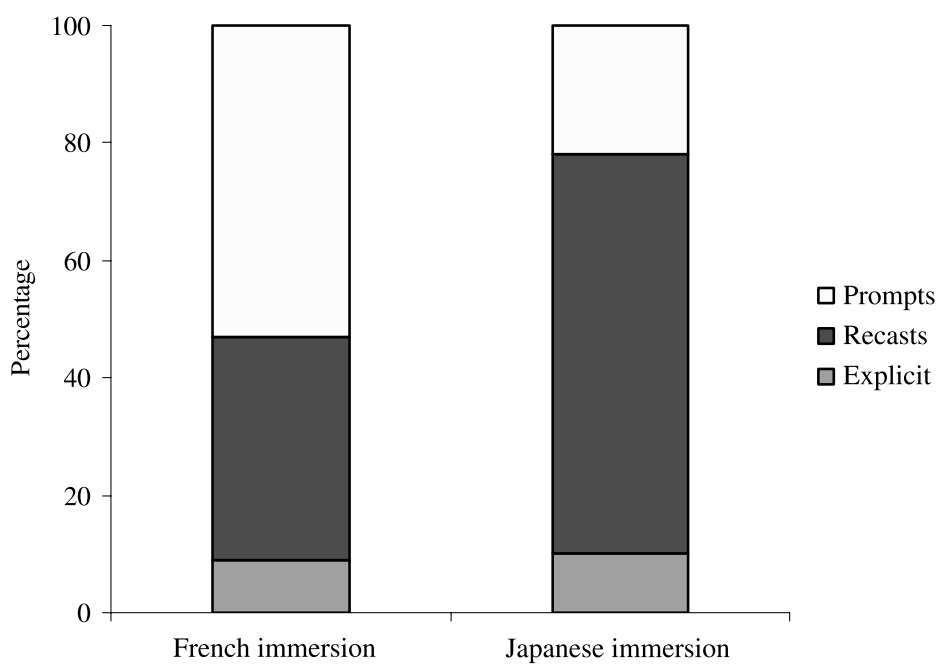

Figure 3. Total distribution of repair across feedback types. 
Table 7. Number and percentage distribution of learner uptake moves after feedback types in both contexts

\begin{tabular}{|c|c|c|c|c|c|c|c|c|c|c|c|c|}
\hline \multirow[b]{3}{*}{ Move } & \multicolumn{6}{|c|}{ French immersion } & \multicolumn{6}{|c|}{ Japanese immersion } \\
\hline & \multicolumn{2}{|c|}{ Explicit } & \multicolumn{2}{|c|}{ Recasts } & \multicolumn{2}{|c|}{ Prompts } & \multicolumn{2}{|c|}{ Explicit } & \multicolumn{2}{|c|}{ Recasts } & \multicolumn{2}{|c|}{ Prompts } \\
\hline & $n$ & $\%$ & $n$ & $\%$ & $n$ & $\%$ & $n$ & $\%$ & $n$ & $\%$ & $n$ & $\%$ \\
\hline \multicolumn{13}{|l|}{ Uptake } \\
\hline Repair & 16 & $35 \%$ & 66 & $19 \%$ & 93 & $38 \%$ & 12 & $50 \%$ & 84 & $50 \%$ & 28 & $42 \%$ \\
\hline Needs repair & 7 & $15 \%$ & 44 & $13 \%$ & 122 & $50 \%$ & 6 & $25 \%$ & 37 & $22 \%$ & 31 & $47 \%$ \\
\hline No uptake & 23 & $50 \%$ & 235 & $68 \%$ & 29 & $12 \%$ & 6 & $25 \%$ & 48 & $28 \%$ & 7 & $11 \%$ \\
\hline
\end{tabular}

after each feedback type in both settings, as seen in Table 7 and illustrated in Figure 4. In both instructional settings, prompts accounted for the highest rate of uptake, with $88 \%$ and $89 \%$ of prompts in FI and JI classrooms, respectively, leading to uptake. The rates of repair after prompts were also similar in both settings, with $38 \%$ and $42 \%$ of all prompts in FI and JI classrooms, respectively, leading to repair. The most striking difference between the two instructional settings appears in the effects that recasts have on learner uptake and repair. In JI classrooms, uptake followed $72 \%$ of all recasts and repair followed $50 \%$, whereas in FI classrooms, uptake followed 32\% of all recasts and repair

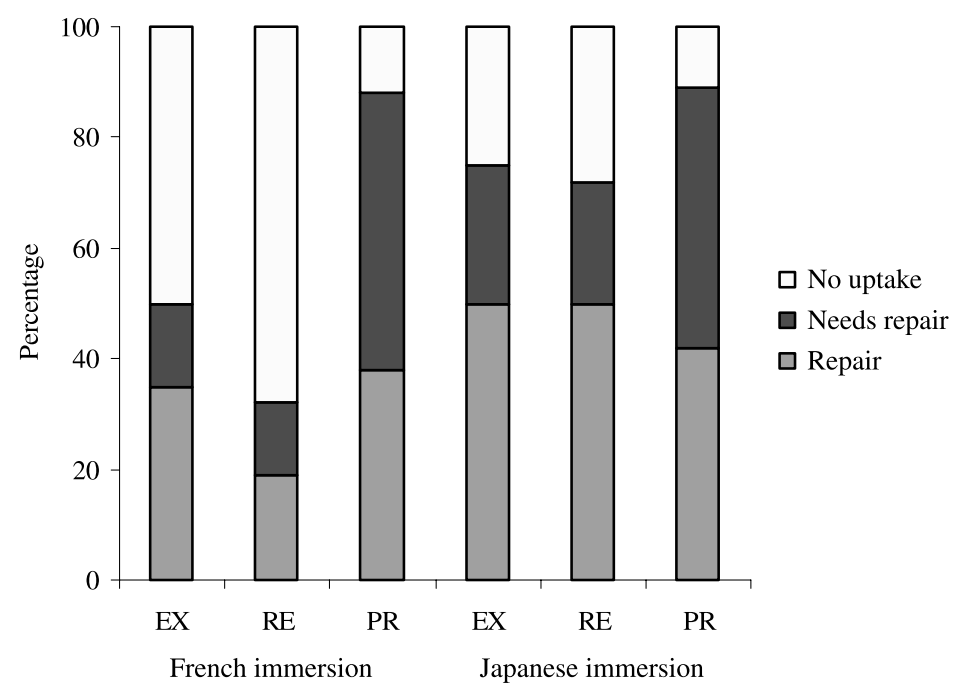

Figure 4. Percentage distribution of learner uptake moves after explicit correction $(\mathrm{EX})$, recasts $(\mathrm{RE})$, and prompts $(\mathrm{PR})$. 
Table 8. Participant organization (percentage distribution of total time)

\begin{tabular}{lcc}
\hline Activity & $\begin{array}{c}\text { French } \\
\text { immersion }\end{array}$ & $\begin{array}{c}\text { Japanese } \\
\text { immersion }\end{array}$ \\
\hline Whole class & & \\
Teacher-led & $62 \%$ & $37 \%$ \\
Student-led & $8 \%$ & $3 \%$ \\
Choral & $0 \%$ & $17 \%$ \\
Individual & $14 \%$ & $29 \%$ \\
Group & $16 \%$ & $14 \%$ \\
\hline
\end{tabular}

followed only $19 \%$. Levels of repair were relatively similar following all three feedback types in JI classrooms. In fact, in JI classrooms, recasts and explicit correction led to almost identical student behavior, which suggests that recasts were as salient as explicit correction in JI classroom discourse. In FI classrooms, however, prompts were more likely to lead to uptake than were recasts or explicit correction, and they were twice as likely as recasts to lead to repair.

The results of the COLT analyses are presented in Tables 8-11. Table 8 shows that participant organization in both immersion settings was structured, for the most part, around whole-class activities. This was the case more so in FI than in JI classrooms, whereas JI students were engaged in individual seat work more often than FI students. One type of whole-class activity that was observed in JI but not FI settings was choral repetition. Students in both settings were engaged in group work for proportionately similar amounts of time.

Table 9 reveals that classroom management, which involved either procedural directives or disciplinary statements, occupied about $10 \%$ of the content focus in both settings. Additionally, a focus on classroom management was observed in combination with a thematic focus $20 \%$ of the time in JI class-

Table 9. Content focus (percentage distribution of total time)

\begin{tabular}{lcc}
\hline Content focus & $\begin{array}{c}\text { French } \\
\text { immersion }\end{array}$ & $\begin{array}{c}\text { Japanese } \\
\text { immersion }\end{array}$ \\
\hline Management & $10 \%$ & $10 \%$ \\
Language & $32 \%$ & $7 \%$ \\
Thematic & $37 \%$ & $48 \%$ \\
Combinations & & \\
$\quad$ Management + theme & $0 \%$ & $20 \%$ \\
$\quad$ Language + theme & $21 \%$ & $15 \%$ \\
\hline
\end{tabular}


Table 10. Content control (percentage distribution of total time)

\begin{tabular}{lcc}
\hline Content control & $\begin{array}{c}\text { French } \\
\text { immersion }\end{array}$ & $\begin{array}{c}\text { Japanese } \\
\text { immersion }\end{array}$ \\
\hline Teacher/text & $83 \%$ & $77 \%$ \\
Teacher/text/student & $17 \%$ & $23 \%$ \\
Students & $0 \%$ & $0 \%$ \\
\hline
\end{tabular}

rooms. A primary focus on language comprised $32 \%$ of the content in FI classrooms but only $7 \%$ of the content in JI classrooms. A primary focus on a language arts or subject-matter theme comprised $37 \%$ of the content in FI settings and $48 \%$ in JI settings. Integration with equal emphasis on language and thematic content comprised 21\% of the content in FI classrooms and 15\% in JI classrooms.

Table 10 reveals only minimal differences across the two settings with respect to content control, which was never completely in the hands of students and was, instead, governed for the most part by teacher and text (only occasionally in collaboration with students). The breakdown of student modality in Table 11 shows that students in both settings spent a significant proportion of their time engaged in various combinations of listening, speaking, reading, and writing. However, FI students spent more time than JI students engaged in activities with a primary focus on either listening or reading in isolation, whereas JI students spent more time than FI students engaged in activities with a primary focus on either speaking or writing in isolation. Oral activities coded in JI classrooms as speaking in isolation involved repetition (including choral repetition) and reading aloud.

The COLT findings confirm that the communicative orientation observed in both immersion settings integrated pedagogical features that varied from analytic to experiential. Students in both settings exercised little or no con-

Table 11. Student modality (percentage distribution of total time)

\begin{tabular}{lcc}
\hline Student modality & $\begin{array}{c}\text { French } \\
\text { immersion }\end{array}$ & $\begin{array}{c}\text { Japanese } \\
\text { immersion }\end{array}$ \\
\hline Listening & $24 \%$ & $16 \%$ \\
Speaking & $5 \%$ & $22 \%$ \\
Reading & $8 \%$ & $2 \%$ \\
Writing & $14 \%$ & $23 \%$ \\
Combinations & $49 \%$ & $37 \%$ \\
\hline
\end{tabular}


trol over the content. In the FI classrooms, content was derived in similar proportions from a language focus and a thematic focus and included many instances of an integrated language and content focus. JI students had minimal exposure to an exclusive focus on language; instead, they received more exposure to content with a thematic focus or content that integrated language with themes or classroom management issues. FI students spent about half their time in activities that integrated more than one language skill (listening, speaking, reading, writing), but spent almost a quarter of their time in activities with a primary focus on listening. JI students spent slightly more than a third of their time in activities that integrated more than one language skill, but spent close to a quarter of their time in activities with a primary focus on speaking, which involved choral repetition or reading aloud. FI students spent $70 \%$ of their time involved in whole-class activities, whereas the remaining time was evenly shared between group and individual activities. JI students spent less time than FI students in teacher-led activities, a similar proportion of time in group activities, but more time doing individual seat work. They also spent time engaged in choral repetition, something that was not observed in FI settings.

\section{DISCUSSION}

To summarize and discuss the results that pertain to interactional feedback, we return to our three research questions. The first research question asked what the distribution of different types of interactional feedback was in FI and JI classrooms. We found that teachers used feedback in similar ways: Recasts constituted the greatest proportion of feedback in both settings (54-65\%), followed by prompts (26-38\%), and then explicit correction (7-9\%). The finding that immersion teachers in both settings behaved similarly in their feedback choices-using recasts much more frequently than other types of feedbackcan be seen as well-tuned to the objectives of content-based L2 instruction, in which recasts play at least one of many possible roles; that is, recasts can serve to (a) provide positive or negative evidence, (b) maintain the flow of communication, (c) keep students' attention focused on content, and (d) scaffold classroom learners as they communicate about subject matter that requires communicative abilities that exceed their current developmental level (Lyster, 2002). The usefulness of recasts in fulfilling one or more of these multiple roles in classroom discourse appears to account for the finding that recasts prevail in L2 classroom interaction regardless of whether the instructional setting consists of children in immersion classrooms (Lyster \& Ranta, 1997; Mori, 2002), adults in ESL classrooms (Ellis et al., 2001; Panova \& Lyster, 2002), children in ESL classrooms (Oliver, 1998), adolescents in EFL classrooms (Tsang, 2004), or adults in French foreign language classrooms (Doughty, 1994).

The second research question asked what distribution of uptake and repair followed different types of interactional feedback in FI and JI classrooms. Dif- 
ferent patterns were observed in FI and JI classrooms: Overall, JI students responded to feedback more frequently (i.e., uptake) and more accurately (i.e., repair) than their FI counterparts. Moreover, the effects of feedback type on uptake and repair were reversed in the two settings: The greatest proportion of uptake and repair in JI settings followed recasts $(61 \%$ and $68 \%$, respectively), whereas the greatest proportion of uptake and repair in FI settings followed prompts ( $62 \%$ and $53 \%$, respectively). Recasts accounted for twice as much uptake than prompts did in JI classrooms, whereas prompts accounted for twice as much uptake than recasts did in FI classrooms. Thus, although no quantitative differences were detected in the teachers' choices of feedback types across instructional settings, clear differences in student behavior were apparent.

The third research question asked what factors contribute to the observed similarities and differences in the occurrence of feedback, uptake, and repair in FI and JI classrooms. The low proportion of learner repair after recasts in FI classrooms was explained in terms of ambiguity by Lyster (1998c), who argued that the pragmatic functions of recasts in classroom discourse obscured their corrective function. JI students, however, were exposed to the same functional range of recasts as FI students through content-based instruction, yet they demonstrated higher rates of uptake and repair. In fact, recasts led to repair as effectively as explicit correction in JI classrooms, which strongly suggests that recasts explicitly served a corrective function in that setting.

Therefore, to answer the third research question, we first refer to the COLT findings and then propose other contextual factors. It appears to be the case that the effectiveness of recasts in eliciting student uptake and repair in JI classrooms is due to at least two instructional design features with an analytic orientation, as detected by the COLT scheme-namely the use of choral repetition and an emphasis on speaking as a skill practiced in isolation through repetition and reading aloud. In other words, we detected an emphasis in JI classrooms on accurate oral production, apparent in various activities involving repetition of teacher models, which likely served to prime JI students for repeating their teachers' recasts. In FI classrooms, the minimal amount of repair that followed recasts was previously explained in terms of redundancy (Lyster, 2004a); that is, when the other (generally the teacher in classroom settings) both initiates and completes repair within a single move, as in the dispreferred conversational move of other-initiated other-correction (see Schegloff, Jefferson, $\&$ Sacks, 1977), the need for the speaker of the trouble source to repeat the correction becomes discursively redundant. We see this in (3), extracted from one of the FI classes: After the teacher's recast ("Elle était jamais allée") of a student's error in the choice of auxiliary and tense, the student simply continues recounting his March break activities without repeating the recast.

(3) Student: Nous sommes allés au Biodôme parce que ma grand-mère elle a jamais allé à là-bas. [grammatical errors]

"We went to the Biodome because my grandmother never goed to there." 


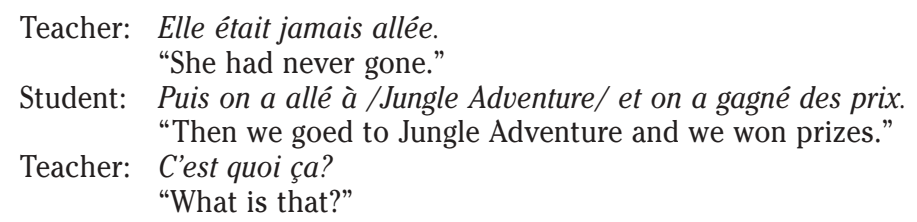

Yet, even though discursively redundant, a student's repetition of a teacher's recast seemed to function as an appropriate and expected student response in JI classrooms, as seen in (4).

(4) Student: Basha o irete to, um, um, toreeru ni mottearimasu. [grammatical errors] "(They) put the wagon in and, um, um, have had (it) to the trail."

Teacher: Ikimasu, motteikimasu. "(They) go, (they) take (it)."

Student: Motteikimasu. "(They) take (it)."

Teacher: Basha no naka ni irete toreeru ni motteiku. Dakara ie no naka ni okimasen. Wakaru?

"(They) put (it) in the wagon and take (it) to the trail. So (they) don't put (it) in the house. Do (you) understand?"

In this example, not only does the student repeat the teacher's recast, but the teacher-following the student's uptake-reformulates the student's first turn (which included multiple errors) in its entirety and then elaborates ("So they don't put it in the house") before concluding with a comprehension check ("Do you understand?"), as if the students' understanding of the message might be contingent on its formal accuracy. In contrast, in the preceding FI example, not only does the student not repeat the teacher's recast, but he continues and makes a similar error, which the teacher ignores and, instead, asks the student to elaborate on the content of his message. The JI example is thus more reminiscent of Seedhouse's (2004) description of form-and-accuracy contexts, in which a student is expected to speak accurately and repeat a teacher's recast as a means of discourse practice. More attention to accuracy in JI than FI settings was further apparent in the finding that JI students produced a smaller proportion of inaccurate utterances during classroom interaction than FI students (13\% vs. $30 \%$, respectively), which suggests that interaction was more tuned to linguistically accurate behavior in JI classrooms than in FI classrooms.

The emphasis on repetition and accurate oral production helps to explain the higher rates of uptake and repair observed in JI classrooms, but not necessarily why JI students were more apt than FI students to notice the corrective function of recasts in the first place. Yet, the overall higher proportion of uptake and repair following feedback in JI classrooms-more specifically, the higher proportion of uptake and repair following recasts-suggests that JI students were predisposed to noticing the corrective purpose of recasts. Their awareness, as demonstrated by a high proportion of uptake and repair moves, 
might have derived from a form-focused orientation in JI settings that resulted from factors not detected by COLT. In what follows, we speculate on factors other than pedagogical and organizational features that arguably primed learners in JI settings to develop attentional biases toward recasts more so than was the case for FI students.

First, differences in language structure and typology are greater between Japanese and English than between French and English. The relationship between French and English as cognate languages that share similar syntactic structures and writing systems arguably creates propitious conditions for a meaning-focused communicative orientation, whereas the fact that Japanese and English are noncognate languages with completely different syntactic structures and different writing systems predisposes JI students and teachers toward a more form-focused orientation.

Second, the FI classrooms were in a typical L2 setting; French is the official language of Quebec and widely used in the Montreal area, thus giving FI students possibilities for exposure to French outside of the classroom. Conversely, the JI classrooms were in a typical foreign language setting; Japanese in the United States is a much less commonly used language, giving JI students negligible exposure to Japanese outside of the classroom. These differences in social setting might have affected overall communicative orientations in predictable ways, making FI instructional settings more meaning-focused and JI instructional settings more form-focused. As Wilkins (1999) suggested, to ensure that a foreign language "is made accessible to the learner under conditions that optimize learning" (p. 657), learners must be exposed to the language system in some structured way. Although JI teachers did not in any apparent way draw on a structural syllabus to support their language instruction, they were adept at integrating analytic teaching strategies to support their content-based lessons.

Therefore, recasts might have been more effective in JI than FI settings because of the observed tendency for JI teachers to regularly integrate choral activities into their content-based instruction, whereby the teachers provided target models and expected students to respond with accurate repetition. This might have served as a priming exercise that incited students to repeat recasts more in JI classrooms than in FI classrooms, where no such instructional strategy was observed. Moreover, it is likely the case that exposure to a typologically different, noncognate foreign language stimulates young learners' attention to form more so than exposure to a typologically similar, cognate L2. Other factors that we did not explore but suggest here for further research are also likely to have played a role-in particular, the teachers' beliefs and behavior as shaped by their professional training and cultural background.

As overt signals used by teachers to draw learners' attention to interlanguage forms, prompts appeared equally effective in both FI and JI settings, but much more so than recasts in FI classrooms. In the absence of isolated oral production practice in FI classrooms-in the form of choral or other types 
of accurate repetition-prompts arguably filled an instructional gap by enabling students to engage in some form of elicited production practice.

\section{CONCLUSION}

We began this paper with a review of classroom-based research into reactive form-focused instruction, which led to the observation that interactional feedback that proves effective in one classroom setting might not be so in another. Specifically, we noted that some classroom studies show a tendency for learners to repeat recasts, whereas other studies show that recasts are ineffective at leading to immediate repair. In terms of longer term effects, recasts in combination with prompts, in the form of repetition of learner error, proved more effective than no feedback in one classroom study, whereas prompts proved more effective than recasts in studies that compared the differential effects of prompts and recasts.

We then compared two different sets of classroom interaction data to arrive at a better understanding of the relevant contextual variables that influence classroom learners' attentional biases toward one type of interactional feedback over another. Building on the results of this and other recent comparative studies, we introduce the notion of instructional counterbalance, presented here as the counterbalance hypothesis:

Instructional activities and interactional feedback that act as a counterbal-
ance to the predominant communicative orientation of a given classroom
setting will be more facilitative of interlanguage restructuring than instruc-
tional activities and interactional feedback that are congruent with the pre-
dominant communicative orientation.

Instructional counterbalance thus refers to interventions that differ from the instructional activities and interactional feedback that otherwise typify the communicative orientation prevailing in a given classroom. Therefore, counterbalanced instruction extends the scope of form-focused instruction by encompassing instructional practices that range from form-focused interventions at one end of the spectrum to meaning-focused interventions at the other. ${ }^{3}$

The counterbalance hypothesis is predicated on the role of attention in L2 learning (see Baddeley \& Logie, 1999; Robinson, 2003; Schmidt, 2001), insofar as interlanguage restructuring is hypothesized to result from the engagement of classroom learners in instructional activities or interactional feedback that require a shift in attentional focus. The effort extended to shift attentional focus from form to meaning in a form-oriented context and from meaning to form in a meaning-oriented context is predicted to strengthen connections between changes in long-term memory and actual language use. Following this prediction, interactional feedback that orients learners in the direction opposite to that to which their target language learning environment has accus- 
tomed them might prove effective in enabling them to restructure their current interlanguage. Skehan (1998) made a similar argument for pushing learners who are either form-oriented or meaning-oriented in the opposite direction in order to strike a balance between the two orientations.

Underlying the counterbalance hypothesis is the assumption that the communicative orientation of a given classroom is easily discernable at one end of the communicative spectrum or the other. In reality, however, it remains difficult to identify classrooms categorically as either completely analytic in orientation or completely experiential. Nevertheless, some activities within and across instructional settings can be identified as more or less analytic and more or less experiential. In the present study, for example, the COLT analysis did not clearly locate FI and JI classrooms at different points along the analytic-experiential continuum, but it did allow for the identification of different types of instructional options with an analytic focus that were integrated into the predominantly experiential backdrop of each immersion setting. What distinguished the two settings most from one another in this regard was the emphasis in JI classrooms on choral repetition and oral production practice in isolation. These analytic features were particular to the JI classrooms, and we speculate that they reveal a form-focused orientation resulting from specific characteristics of the target language-a typologically different, noncognate foreign language-that served to focus the attention of both teachers and students more on form than would a typologically similar, cognate L2, such as French. We appeal to these differences to illustrate the counterbalance hypothesis and to explain differences detected in learner responses to interactional feedback across both settings.

First, the counterbalance hypothesis predicts that recasts-implicit and naturalistic feedback moves contingent on meaning-are effective for learners in classroom settings in which the communicative orientation permits regular opportunities for controlled production practice with an emphasis on accuracy. Classroom activities that include choral and other types of repetition are likely to bias learners' attention toward form in ways that predispose them to notice the corrective function of recasts (i.e., to notice the gap between their nontarget output and the teacher's recast and to follow up with a repair move). In these classrooms, recasts have the potential to unambiguously play their double role as both corrective and pragmatic moves, as they draw attention to form on the one hand and confirm the veracity of the learner's utterance on the other. As discourse moves that are well suited to meaningful interaction, recasts enable learners in these classrooms to reorient their attentional resources toward meaning in ways that avert an overemphasis on form at the expense of meaning. As Tomlin and Villa (1994) argued, learners who bias attentional resources toward linguistic form benefit from their ability to detect formal distinctions "but perhaps at the cost of failing to detect other components of input utterances" (p. 199).

Second, the counterbalance hypothesis predicts that prompts are effective for learners in classroom settings in which the communicative orientation does 
not favor opportunities for controlled production practice with an emphasis on accuracy. It is predicted that learners unaccustomed to any accuracybased oral production practice will (a) detect prompts more easily than the covert signals they need to infer from recasts, (b) benefit from being overtly prompted to shift their attentional resources toward form and momentarily away from meaning, and (c) benefit from the opportunities to produce modified output in the form of self-repair after prompts. These predictions are supported by Skehan's (1998) contention that learners who emphasize meaning over form in production will benefit from being pushed to confront issues of form.

However, as already mentioned, because classrooms do not necessarily fit into only one type of communicative orientation, we acknowledge-at least with respect to interactional feedback - that L2 learners from a wide range of instructional settings are likely to benefit from a balanced provision of both recasts and prompts. Depending on the interactional context (Oliver \& Mackey, 2003), learners are likely to notice the corrective quality of a good number of recasts and to benefit from other less salient recasts, especially in cases (a) where the recasts have been shortened, or provided with added stress to highlight the error, or both and (b) where the target forms are beyond the students' current abilities. In many other instances, learners will benefit from being pushed to produce modified output by means of prompting, especially in cases (a) where recasts could be perceived ambiguously as approving their use of nontarget forms and (b) where learners have reached a developmental plateau in their use of the nontarget forms.

In addition to its predictions about the optimal effectiveness of interactional feedback, the counterbalance hypothesis pertains also to other instructional interventions. The counterbalance hypothesis finds support in this regard from a recent review of form-focused instructional treatments in FI classrooms (Lyster, 2004b), which revealed that the most effective form-focused instructional interventions (with the most robust results) were those that differed the most from other instructional activities going on at the same time in other parts of the immersion curriculum. Lyster's comparison of studies by Day and Shapson (1991), Harley $(1989,1998)$, and Lyster $(1994,2004 a)$ showed that the most effective instructional activities-at least with respect to interlanguage features that had reached a developmental plateau-included a balanced distribution of opportunities for noticing, language awareness, and controlled practice with feedback and thereby differed from other types of content-based activity routinely encountered in FI classrooms. Instructional treatments that provided continued opportunities for the same type of meaning-based interaction so characteristic of immersion classroom discourse proved much less effective at changing the students' use of easily accessible interlanguage forms.

On a final note, we comment on our study's limitations and point to future research directions. As formulated, the counterbalance hypothesis accounts for communicative orientation as a learner-external variable within a given classroom setting, without acknowledging the importance of learner-internal 
variables. To factor individual differences into the equation, we note that proficiency level is emerging as an important variable in feedback appreciation and, thus, as a topic ripe for further research. In addition to the impact of length of study (e.g., grade level), proficiency as a relevant variable affecting interactional feedback is reflected in individual differences such as developmental readiness (Mackey \& Philp, 1998), test performance (Ammar, 2003; Havranek \& Cesnik, 2001), and aptitude, which includes working memory capacity (Miyake \& Friedman, 1998) and language analytic ability (Ranta, 2002). Additionally, the present study did not take into account the different types of errors made by students and how these affect choice of feedback and learner repair in each setting. It will be worth conducting further research to investigate how these factors are related to the counterbalance hypothesis. Finally, the present study examined classrooms that targeted two different languages across three types of immersion programs. Future studies could aim for more fine-grained comparisons, controlling variables such as program type and target language to investigate differences and similarities that emerge, for instance, in early total FI classrooms across L2 versus foreign language settings.

The notion of instructional counterbalance is proposed here to stimulate further investigation into the effectiveness of interactional feedback and other instructional interventions designed to counterbalance the predominant communicative orientation in a range of L2 classroom settings. Implemented by selectively shifting learners' attention away from the predominant communicative orientation of the instructional setting, counterbalanced intervention has promising potential as a catalyst for interlanguage restructuring and continued L2 growth.

\section{NOTES}

1. These and subsequent examples of feedback are from the French and Japanese immersion classrooms observed in the present study.

2. The impact of error type on choice of feedback and on learner repair is reported elsewhere (Lyster, 1998b; Mori, 2002). Note also that the present study excludes unsolicited uses of L1 as errors (cf. Lyster; Lyster \& Ranta, 1997).

3. Interventions refer here to instructional treatments that are employed more for the purpose of effecting changes in classroom learners' use of interlanguage forms than for exposing them to completely new linguistic information.

\section{REFERENCES}

Allen, P. (1983). A three-level curriculum model for second-language education. Canadian Modern Language Review, 40, 23-43.

Allen, P., Fröhlich, M., \& Spada, N. (1984). The communicative orientation of second language teaching: An observation scheme. In J. Handscombe, R. Orem, \& B. Taylor (Eds.), On TESOL '83 (pp. 231-252). Washington, DC: TESOL.

Allen, P., Swain, M., Harley, B., \& Cummins, J. (1990). Aspects of classroom treatment: Toward a more comprehensive view of second language education. In B. Harley, P. Allen, J. Cummins, \& M. Swain (Eds.), The development of second language proficiency (pp. 57-81). New York: Cambridge University Press.

Ammar, A. (2003). Corrective feedback and L2 learning: Elicitation and recasts. Unpublished doctoral dissertation, McGill University, Montreal. 
Aston, G. (1988). Trouble-shooting in interaction with learners: The more the merrier? Applied Linguistics, 7, 128-143.

Baddeley, A., \& Logie, R. (1999). Working memory: The multiple-component model. In A. Miyake \& P. Shah (Eds.), Models of working memory (pp. 28-61). New York: Cambridge University Press.

Braidi, S. (2002). Reexamining the role of recasts in native-speaker/nonnative-speaker interactions. Language Learning, 52, 1-42.

Chaudron, C. (1988). Second language classrooms. New York: Cambridge University Press.

Day, E., \& Shapson, S. (1991). Integrating formal and functional approaches to language teaching in French immersion: An experimental study. Language Learning, 41, 25-58.

de Bot, K. (1996). The psycholinguistics of the output hypothesis. Language Learning, 46, 529-555.

Doughty, C. (1994). Finetuning of feedback by competent speakers to language learners. In J. Alatis (Ed.), GURT 1993: Strategic interaction (pp. 96-108). Washington, DC: Georgetown University Press.

Doughty, C. (2001). Cognitive underpinning of focus on form. In P. Robinson (Ed.), Cognition and second language instruction (pp. 206-257). New York: Cambridge University Press.

Doughty, C., \& Varela, E. (1998). Communicative focus on form. In C. Doughty \& J. Williams (Eds.), Focus on form in classroom second language acquisition (pp. 129-154). New York: Cambridge University Press.

Doughty, C., \& Williams, J. (1998). Pedagogical choices in focus on form. In C. Doughty \& J. Williams (Eds.), Focus on form in classroom second language acquisition (pp. 197-261). New York: Cambridge University Press.

Ellis, R. (2001). Investigating form-focused instruction. Language Learning, 51(Suppl. 1), 1-46.

Ellis, R., Basturkmen, H., \& Loewen, S. (2001). Learner uptake in communicative ESL lessons. Language Learning, 51, 281-318.

Fazio, L., \& Lyster, R. (1998). Immersion and submersion classrooms: A comparison of instructional practices in language arts. Journal of Multilingual and Multicultural Development, 19, 303-317.

Foster, P. (1998). Classroom perspective on the negotiation of meaning. Applied Linguistics, 19, $1-23$.

Fröhlich, M., Spada, N., \& Allen, P. (1985). Differences in the communicative orientation of L2 classrooms. TESOL Quarterly, 19, 27-57.

Harley, B. (1989). Functional grammar in French immersion: A classroom experiment. Applied Linguistics, 10, 331-359.

Harley, B. (1998). The role of form-focused tasks in promoting child L2 acquisition. In C. Doughty \& J. Williams (Eds.), Focus on form in classroom second language acquisition (pp. 156-174). New York: Cambridge University Press.

Havranek, G. (2002). When is corrective feedback most likely to succeed? International Journal of Educational Research, 37, 255-270.

Havranek, G., \& Cesnik, H. (2001). Factors affecting the success of corrective feedback. EUROSLA Yearbook, 1, 99-122.

Krashen, S. (1994). The input hypothesis and its rivals. In N. Ellis (Ed.), Implicit and explicit learning of languages (pp. 45-77). San Diego, CA: Academic Press.

Lapkin, S., \& Swain, M. (1996). Vocabulary teaching in a grade 8 French immersion class: A descriptive case study. Canadian Modern Language Review, 53, 242-256.

Laplante, B. (1993). Stratégies pédagogiques et enseignement des sciences en immersion française: Le cas d'une enseignante [Pedagogical strategies and science teaching in French immersion: The case of one teacher]. Canadian Modern Language Review, 49, 567-588.

Leeman, J. (2003). Recasts and second language development: Beyond negative evidence. Studies in Second Language Acquisition, 25, 37-63.

Lightbown, P. (1991). What have we here? Some observations on the influence of instruction on L2 learning. In R. Phillipson, E. Kellerman, L. Selinker, M. Sharwood Smith, \& M. Swain (Eds.), Foreign/ second language pedagogy research (pp. 197-212). Clevedon, UK: Multilingual Matters.

Lightbown, P. (1998). The importance of timing in focus on form. In C. Doughty \& J. Williams (Eds.), Focus on form in classroom second language acquisition (pp. 177-196). New York: Cambridge University Press.

Lightbown, P., \& Spada, N. (1990). Focus on form and corrective feedback in communicative language teaching: Effects on second language learning. Studies in Second Language Acquisition, $12,429-448$.

Lochtman, K. (2002). Oral corrective feedback in the foreign language classroom: How it affects interaction in analytic foreign language teaching. International Journal of Educational Research, 37, 271-283.

Loewen, S. (2004). Uptake in incidental focus on form in meaning-focused ESL lessons. Language Learning, 54, 153-188. 
Loewen, S. (2005). Incidental focus on form and second language learning. Studies in Second Language Acquisition, 27, 361-386.

Long, M. H. (1977). Teacher feedback on learner error: Mapping cognitions. In H. D. Brown, C. A. Yorio, \& R. H. Crymes (Eds.), On TESOL '77 (pp. 278-293). Washington, DC: TESOL.

Long, M. H. (1991). Focus on form: A design feature in language teaching methodology. In K. de Bot, R. Ginsberg, \& C. Kramsch (Eds.), Foreign language research in cross-cultural perspectives (pp. 3952). Amsterdam: Benjamins.

Long, M. H. (1996). The role of the linguistic environment in second language acquisition. In W. C. Ritchie \& T. K. Bhatia (Eds.), Handbook of second language acquisition (pp. 413-468), San Diego, CA: Academic Press.

Long, M. H., \& Robinson, P. (1998). Focus on form: Theory, research, and practice. In C. Doughty \& J. Williams (Eds.), Focus on form in classroom second language acquisition (pp. 15-41). New York: Cambridge University Press.

Lyster, R. (1994). The effect of functional-analytic teaching on aspects of French immersion students' sociolinguistic competence. Applied Linguistics, 15, 263-287.

Lyster, R. (1998a). Immersion pedagogy and implications for language teaching. In J. Cenoz \& F. Genesee (Eds.), Beyond bilingualism: Multilingualism and multilingual education (pp. 64-95). Clevedon, UK: Multilingual Matters.

Lyster, R. (1998b). Negotiation of form, recasts, and explicit correction in relation to error types and learner repair in immersion classrooms. Language Learning, 48, 183-218.

Lyster, R. (1998c). Recasts, repetition, and ambiguity in L2 classroom discourse. Studies in Second Language Acquisition, 20, 51-81.

Lyster, R. (2002). Negotiation in immersion teacher-student interaction. International Journal of Educational Research, 37, 237-253.

Lyster, R. (2004a). Differential effects of prompts and recasts in form-focused instruction. Studies in Second Language Acquisition, 26, 399-432.

Lyster, R. (2004b). Research on form-focused instruction in immersion classrooms: Implications for theory and practice. Journal of French Language Studies, 14, 321-341.

Lyster, R., \& Ranta, L. (1997). Corrective feedback and learner uptake. Studies in Second Language Acquisition, 19, 37-66.

Mackey, A., Gass, S., \& McDonough, K. (2000). How do learners perceive interactional feedback? Studies in Second Language Acquisition, 22, 471-497.

Mackey, A., \& Philp, J. (1998). Conversational interaction and second language development: Recasts, responses, and red herrings? Modern Language Journal, 82, 338-356.

McDonough, K. (2005). Identifying the impact of negative feedback and learners' responses on ESL question development. Studies in Second Language Acquisition, 27, 79-103.

Miyake, A., \& Friedman, N. (1998). Individual differences in second language proficiency: Working memory as language aptitude. In A. Healy \& L. Bourne (Eds.), Foreign language learning: Psycholinguistic studies on training and retention (pp. 339-364). Mahwah, NJ: Erlbaum.

Mori, H. (2000). Error treatment at different grade levels in Japanese immersion classroom interaction. Studies in Language Sciences, 1, 171-180.

Mori, H. (2002). Error treatment sequences in Japanese immersion classroom interactions at different grade levels. Unpublished doctoral dissertation, University of California, Los Angeles.

Nicholas, H., Lightbown, P., \& Spada, N. (2001). Recasts as feedback to language learners. Language Learning, 51, 719-758.

Norris, J., \& Ortega, L. (2000). Effectiveness of L2 instruction: A research synthesis and quantitative meta-analysis. Language Learning, 50, 417-528.

Oliver, R. (1998). Negotiation of meaning in child interactions. Modern Language Journal, 82, 372-386.

Oliver, R., \& Mackey, A. (2003). Interactional context and feedback in child ESL classrooms. Modern Language Journal, 87, 519-533.

Oshima-Takane, Y., MacWhinney, B., Sirai, H., Miyata, S., \& Naka, N. (Eds.). (1998). CHILDES for Japanese (2nd ed.). The JCHAT Project, Nagoya: Chukyo University.

Panova, I., \& Lyster, R. (2002). Patterns of corrective feedback and uptake in an adult ESL classroom. TESOL Quarterly, 36, 573-595.

Pica, T. (1994). Research on negotiation: What does it reveal about second-language learning conditions, processes, and outcomes? Language Learning, 44, 493-527.

Ranta, L. (2002). The role of learners' language analytic ability in the communicative classroom. In P. Robinson (Ed.), Individual differences and instructed language learning (pp. 159-180). Amsterdam: Benjamins.

Ranta, L., \& Lyster, R. (in press). A cognitive approach to improving immersion students' oral language abilities: The awareness-practice-feedback sequence. In R. DeKeyser (Ed.), Practicing for 
second language use: Perspectives from applied linguistics and cognitive psychology. New York: Cambridge University Press.

Roberts, M. (1995). Awareness and the efficacy of error correction. In R. Schmidt (Ed.), Attention and awareness in foreign language learning (Tech. Rep. No. 9, pp. 162-182). Honolulu: University of Hawai'i.

Robinson, P. (2003). Attention and memory in SLA. In C. Doughty \& M. H. Long (Eds.), The handbook of second language acquisition (pp. 631-678). Oxford: Blackwell.

Schegloff, E., Jefferson, G., \& Sacks, H. (1977). The preference for self-correction in the organization of repair in conversation. Language, 53, 361-382.

Schmidt, R. (2001). Attention. In P. Robinson (Ed.), Cognition and second language instruction (pp. 332). New York: Cambridge University Press.

Seedhouse, P. (2004). The interactional architecture of the language classroom: A conversation analysis perspective. Oxford: Blackwell.

Sheen, Y. (2004). Corrective feedback and learner uptake in communicative classrooms across instructional settings. Language Teaching Research, 8, 263-300.

Skehan, P. (1998). A cognitive approach to language learning. Oxford: Oxford University Press.

Spada, N. (1997). Form-focused instruction and second language acquisition: A review of classroom and laboratory research. Language Teaching, 29, 1-15.

Spada, N., \& Fröhlich, M. (1995). COLT. Communicative orientation of language teaching observation scheme: Coding conventions and applications. Sydney: National Centre for English Language Teaching and Research.

Spada, N., \& Lightbown, P. (1993). Instruction and the development of questions in the L2 classroom. Studies in Second Language Acquisition, 15, 205-221.

Stern, H. H. (1990). Analysis and experience as variables in second language pedagogy. In B. Harley, P. Allen, J. Cummins, \& M. Swain (Eds.), The development of second language proficiency (pp. 93109). New York: Cambridge University Press.

Stern, H. H. (1992). Issues and options in language teaching (P. Allen \& B. Harley, Eds.). Oxford: Oxford University Press.

Swain, M. (1985). Communicative competence: Some roles of comprehensible input and comprehensible output in its development. In S. M. Gass \& C. Madden (Eds.), Input in second language acquisition (pp. 235-253). Rowley, MA: Newbury House.

Swain, M. (1988). Manipulating and complementing content teaching to maximize second language teaching. TESL Canada Journal, 6, 68-83.

Thornton, I., \& Pienemann, M. (1994). COALA: Computer-aided linguistic analysis. Sydney: Language Acquisition Research Centre.

Tomasello, M., \& Herron, C. (1988). Down the garden path: Inducing and correcting overgeneralization errors in the foreign language classroom. Applied Psycholinguistics, 9, 237-246.

Tomasello, M., \& Herron, C. (1989). Feedback for language transfer errors: The garden path technique. Studies in Second Language Acquisition, 11, 385-395.

Tomlin, R., \& Villa, V. (1994). Attention in cognitive science and second language acquisition. Studies in Second Language Acquisition, 16, 183-203.

Truscott, J. (1999). What's wrong with oral grammar correction. Canadian Modern Language Review, $55,437-456$.

Tsang, W. (2004). Feedback and uptake in teacher-student interaction: An analysis of 18 English lessons in Hong Kong secondary classrooms. Regional Language Centre Journal, 35, 187-209.

White, J. (1998). Getting the learners' attention: A typographical input enhancement study. In C. Doughty \& J. Williams (Eds.), Focus on form in classroom second language acquisition (pp. 85113). New York: Cambridge University Press.

White, L. (1987). Against comprehensible input: The input hypothesis and the development of secondlanguage competence. Applied Linguistics, 8, 95-110.

Wilkins, D. (1999). Second language teaching. In B. Spolsky (Ed.), Concise encyclopedia of educational linguistics (pp. 656-658). Oxford: Pergamon. 